Short paper

\title{
Analysis of rainfall trends and variabilities for three decades in Sub - Sahara Africa
}

Francis O. Aweda ${ }^{* 1}$, Adetunji A. Adeniji ${ }^{1}$, Jacob A. Akinpelu ${ }^{1}$ and Ayodele J. Abiodun ${ }^{2}$

${ }^{1}$ Physics and Solar Energy Programme, College of Agriculture, Engineering, and Science, Bowen University, Iwo, Osun State, Nigeria.

${ }^{2}$ Department of Physics, Faculty of Sciences, Lead City University, Ibadan, Oyo State, Nigeria

*Correspondence: francisaweda@gmail.com; (D) ORCID: https://orcid.org/0000-0003-3941-6647

Received: $30^{\text {th }}$ November 2020, Revised: $29^{\text {th }}$ June 2021, Accepted: $30^{\text {th }}$ June 2021

\begin{abstract}
Rainfall trend is an important climatic factor that influences agricultural products, groundwater production, drainage planning, commercial and industrial activities. The research aims to determine the trends and variability of monthly, seasonal, and annual rainfall for 30 years (from 1980 to 2010$)$ in Sokoto $\left(13.0059^{\circ} \mathrm{N}\right.$, $\left.5.2476^{\circ} \mathrm{E}\right)$ and Maiduguri (11.8333 $\left.\mathrm{N}, 13.1500^{\circ} \mathrm{E}\right)$ using archives data obtained from the Nigeria Meteorological Agency (NiMet), Oshodi Lagos Nigeria. Statistical models were used to analyze the data. The results reveal that the maximum rainfall recorded was $371.60 \mathrm{~mm}$ at Maiduguri station and $374.90 \mathrm{~mm}$ at Sokoto station which shows a higher rainfall peak in Sokoto than Maiduguri. The coefficient of variation in the Sokoto station (126.39\%) was higher than that of Maiduguri station $(61.78 \%)$ which indicates that there was more rainfall variability in Sokoto than in Maiduguri. Seasonally, the average rainfall recorded in both stations was $61.78 \%$ and $126.39 \%$ respectively. No rainfall was recorded in January, February, and November for Maiduguri station, more so, no rainfall was recorded in January, November, and December for Sokoto station. According to Man-Kendal trend analysis, significant trends $(\mathrm{p}<0.5)$ were observed in Maiduguri and Sokoto. Therefore, the modelled statistical approach on rainfall trends and variability revealed that the peak month of annual rainfall is between June and September for the two stations. It can be recommended that the government should make favourable policies to utilize the rainfall received during this period to store more water in reservoirs and construction of water channels across the country.
\end{abstract}

Keywords: Atmospheric, Kolmogorov, Mann-Kendal, Rainfall, water resources.

\section{Introduction}

The trend of rainfall and its variability over the sub-Sahara region of Africa is an important requirement for the planning and management of water resources and is 
useful for agricultural irrigation farm practice and drinking purposes. Irrigation farming is one of the major activities of Northern Nigeria. In this region, typical shallow-well hand-pump is mainly utilized to extract groundwater while surface water sources like streams and rivers are also used to obtain water for drinking and other water requirements. Water resource management engages with engineering activities that require adequate knowledge about the variation of rainfall and its temporal pattern (Oloruntade et al. 2018). Recent weather variations which have increased worldwide inconsistency of the hydrological cycle generate uncertainties concerning the forecast of future climate conditions, and the associated impact on the studies of long-term climate series have become increasingly necessary (Houghton et al. 1996). According to Abdul Aziz and Burn (2006), planning, designing, and operating of water reservoirs have a great impact on the variability quality and demand of water in the rural areas of Nigeria. However, Oguntade et al. (2011) stated that the behaviour of rainfall patterns in any area has an impact on the social and economic significance of the location. In this regard, hydrologists are encouraged to study the behaviour of the rainfall patterns through statistical analysis by predicting and forecasting rainfall patterns across the globe (Oloruntade et al.2018).

There are different kinds of floods experienced in the entire country due to the overflow of the ocean and rivers. Different researchers have found out that extreme rainfall events cause floods across the country (Oloruntade et al. 2018). As reported by Oloruntade et al. (2018), a flood disaster that occurred in 2012 destroyed properties that were valued at about 40 billion Naira (219.6 million USD), and damaged nine local government areas of Kogi State including the state capital Lokoja. Nigeria being a country where agriculture especially in the Northern part of the country plays a major role in the economy to meet the rising demands for food and potable water requires more judicious use of water in both irrigation and rain-fed agriculture (Smith 2000). Several studies carried out on rainfall time series across the world revealed that the effects were either positive or negative on the trends of rainfall (Oloruntade et al. 2018). Authors like Xu et al. (2010), Wang et al. (2011) and Anghileri et al. (2014) examined the monotonic trend of rainfall and its changes across different locations in the world. However, time series analysis of rainfall revealed either decreasing or increasing trends depending on the location (Mondal et al. 2012). Further, Shahid (2010) studied the trend of annual rainfall in Bangladesh during the 1958-2007 period and reported a significant increase in the average annual rainfall. As reported by Oloruntade et al. (2018), there is spatial and temporal scale variability and trend in rainfall across the Africa continent, particularly in the West Africa sub-region. Different rainfall trends reported across Nigeria (Adefolalu 2007, Abaje et al. 2010, Akinsanola and Ogunjobi 2014) observed that there were dry days in June and October over a study conducted in Kafanchan in the guinea savanna ecological belt of Nigeria during 1974 to 1983 and 1999 to 2008. Also, Abaje et al. (2010) revealed that there are significant dry conditions in June and October during the period from 1974 to 1983 and from 1999 to 2008, respectively. Therefore, this research focused on the study of rainfall trends and the variability of rainfall over sub-Sahara stations in Sokoto and Maiduguri located in the Northern 
part of the country. This study was based on monthly average rainfall data collected from the Nigeria meteorological agency station (NiMet) over 30 years from 1980 to 2010 to investigate the trends and patterns across Nigeria.

\section{Methods}

The vegetation zone of the entire country with both locations Sokoto and Maiduguri located in the Sahel region of the country is shown in Figure 1.

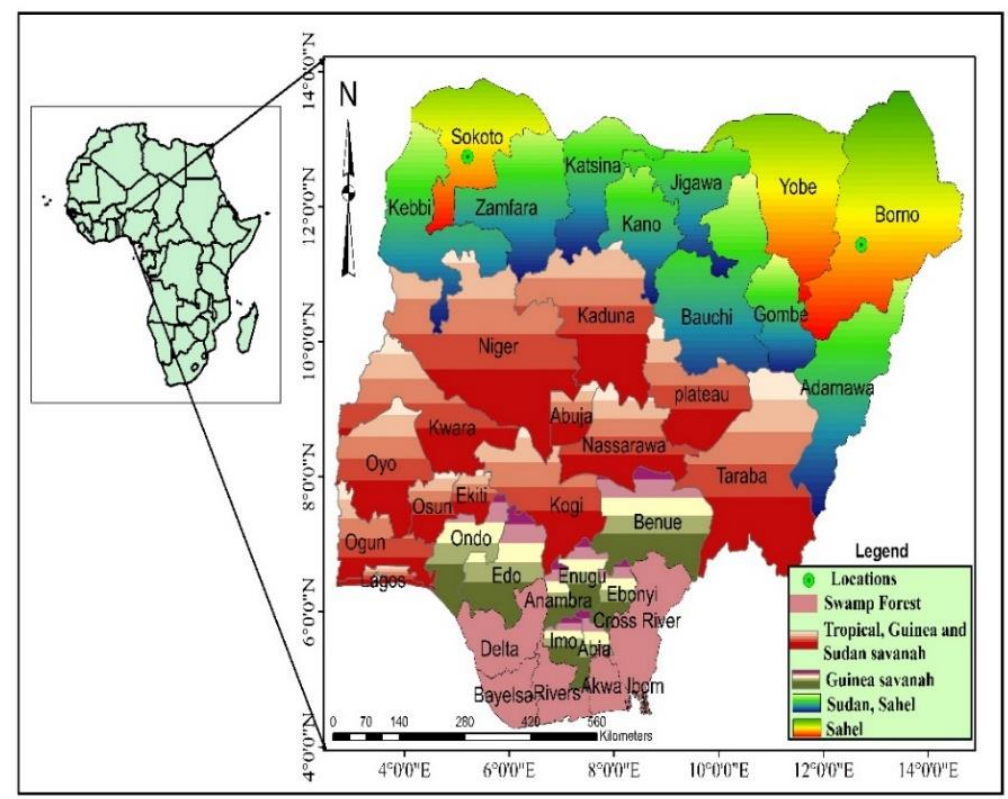

Fig 1: Map of Nigeria showing the two locations and vegetation zone.

Rainfall data at Sokoto $\left(13.0059^{\circ} \mathrm{N}, 5.2476^{\circ} \mathrm{E}\right)$ and Maiduguri $\left(11.8333^{\circ} \mathrm{N}\right.$, $13.1500^{\circ}$ E) stations recorded by the Nigeria Meteorological Agency (NiMet), Oshodi Lagos, Nigeria is used in this research. Using statistical packages, these data were analyzed to determine the trend and variability of rainfall at two stations. Descriptive statistics including means, minimum, maximum, skewness, kurtosis, and coefficient of variation were computed using rainfall data at Sokoto and Maiduguri stations. The Mann- Kendal statistics was used to analyze the rainfall trend while the normality of rainfall was determined using the Kolmogorov-Smirnov test. The comparison of the monthly rainfall at the locations was carried out using the MannWhitney test and a p-value less than 0.05 was considered statistically significant. Also, linear regression was used to estimate the trend in the rainfall data. These statistical analyses were carried out using STATA, SPSS, and MS Excel. The 
analysis of the trend using the Mann-Kendall test was developed at the Meteorological institute (Salami et al. 2002) using a spreadsheet (Makesen 1.0), and we used that to analyze and interpret rainfall trends in this study. Annual rainfall, altitude and classification of the two locations are given in Table 1.

Table 1: Geographical location, annual rainfall, and climatic classification of the two stations.

\begin{tabular}{lccccc}
\hline Location & Latitude $^{\circ} \mathrm{N}$ & Longitude $^{\circ} \mathrm{E}$ & $\begin{array}{c}\text { Altitude } \\
(\mathrm{m})\end{array}$ & $\begin{array}{c}\text { Annual rainfall } \\
(\mathrm{mm})\end{array}$ & Climatic Classification \\
\hline Sokoto & 13.0059 & 5.2476 & 281 & 950 & Tropical Continental \\
Maiduguri & 11.8333 & 13.1500 & 354 & 1000 & Tropical Continental \\
\hline
\end{tabular}

\section{Results and Discussion}

Descriptive statistics including variability in rainfall at Sokoto and Maiduguri stations are presented in Tables 2 and 3. This result reveals that the maximum rainfall recorded was $371.60 \mathrm{~mm}$ at Maiduguri station and $374.90 \mathrm{~mm}$ at Sokoto station which shows a higher rainfall peak in Sokoto than Maiduguri.

Table 2: Descriptive statistics for rainfall data (1980-2010) in Sokoto, Nigeria.

\begin{tabular}{llcrrrrr}
\hline Month & Min. & Max. & Mean & SD & Skewness & Kurtosis & COV (\%) \\
\hline January & - & - & - & - & - & - & - \\
February & - & 2.80 & 0.09 & 0.50 & 5.57 & 31.00 & 556.78 \\
March & - & 33.30 & 2.79 & 8.22 & 3.27 & 10.13 & 294.44 \\
April & - & 30.80 & 4.58 & 7.98 & 2.03 & 3.64 & 174.13 \\
May & - & 141.40 & 50.28 & 40.25 & 0.98 & 0.26 & 80.06 \\
June & 23.70 & 287.90 & 96.64 & 62.22 & 1.36 & 1.89 & 64.39 \\
July & 56.80 & 361.60 & 187.95 & 80.21 & 0.94 & 0.19 & 42.68 \\
August & 67.20 & 357.60 & 189.18 & 74.42 & 0.87 & 0.10 & 39.34 \\
September & - & 374.90 & 97.43 & 71.13 & 2.04 & 6.84 & 73.01 \\
October & - & 122.90 & 16.06 & 30.81 & 2.83 & 7.93 & 191.88 \\
November & - & - & - & - & - & - & - \\
December & - & - & - & - & - & - & - \\
Overall & 49.23 & 374.90 & 53.75 & 32.81 & 1.10 & 3.49 & 126.39 \\
\hline
\end{tabular}

$\mathrm{COV}=$ Coefficient of variation (\%), no data available (-)

The overall coefficient of variation in Sokoto station (126.39\%) was higher than Maiduguri station (61.78\%). Monthly rainfall data are positively skewed in both locations indicating that the monthly rainfall within the study period has increased. The mean rainfalls in Sokoto in most of the months were higher than those in Maiduguri. However, the highest COV recorded in Sokoto was in February (556.78\%), and Maiduguri was in May (29.80\%). 
Table 3: Descriptive statistics for rainfall data (1980-2010) in Maiduguri, Nigeria.

\begin{tabular}{lcrrrcrc}
\hline Month & Min. & Max. & Mean & SD & Skewness & Kurtosis & COV (\%) \\
\hline January & - & \multicolumn{1}{c}{-} & - & - & - & - & - \\
February & - & - & - & - & - & - & - \\
March & - & 7.50 & 0.33 & 1.39 & 4.97 & 25.71 & 18.53 \\
April & - & 60.90 & 7.57 & 12.31 & 3.01 & 11.41 & 20.21 \\
May & - & 78.10 & 29.54 & 23.27 & 0.65 & -0.36 & 29.80 \\
June & 10.20 & 371.60 & 74.36 & 65.70 & 3.26 & 13.97 & 17.68 \\
July & 56.90 & 342.70 & 169.01 & 68.49 & 0.59 & 0.08 & 19.98 \\
August & 67.30 & 296.40 & 183.79 & 64.16 & 0.03 & 0.80 & 21.65 \\
September & 0.30 & 231.80 & 97.74 & 62.14 & 0.54 & -0.53 & 26.81 \\
October & - & 81.70 & 13.32 & 19.54 & 1.99 & 4.36 & 23.92 \\
November & - & 0.00 & 0.00 & 0.00 & - & - & - \\
December & - & 2.50 & 0.08 & 0.45 & 5.57 & 31.00 & 17.96 \\
Overall & 122.7 & 371.60 & 47.98 & 29.64 & 0.32 & 0.001 & 61.78 \\
\hline
\end{tabular}

$\mathrm{COV}=$ Coefficient of variation (\%), no data available (-)

In Maiduguri, the minimum rainfall was observed in 1982 and the maximum in 2008 (Figure 2 (a)). However, the minimum and maximum rainfall recorded in Sokoto was in 1988 and 2010, respectively. As revealed in Figure 2(b), the maximum monthly rainfall was recorded in Sokoto (about $185 \mathrm{~mm}$ ), while in Maiduguri it was about 180 $\mathrm{mm}$. No rainfall was recorded in January, February, November, and December for the two stations.
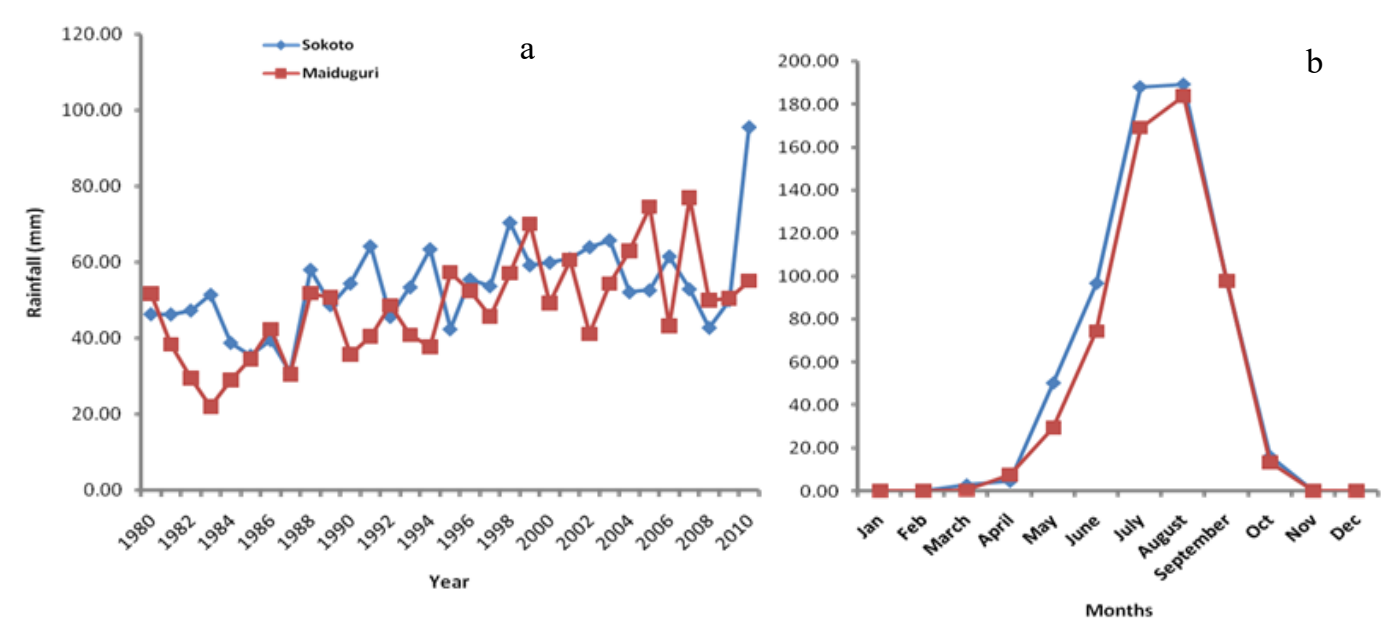

Fig 2: (a) Annual average rainfall, and (b) monthly average rainfall in Sokoto and Maiduguri (1980-2010). 
The summary result of the trend analysis of rainfall in Sokoto and Maiduguri using Mann-Kendal (MK) statistics is given the Table 4. According to these results, there is an increasing trend in monthly rainfall in almost all months other than February in Sokoto. In February, Sokoto showed a declined trend $(\mathrm{Z}=-0.450, \mathrm{p}=0.655)$. Similarly, Maiduguri showed an upward trend of monthly rainfall in most of the months. Also, it was observed that there was a significant upward monthly rainfall trend in August at Maiduguri while March and December showed a non-significant decreasing trend ( $>>0.05)$.

Table 4: Man-Kendal trend analysis for monthly and overall rainfall in Sokoto and Maiduguri.

\begin{tabular}{lcccc}
\hline \multirow{2}{*}{ Month } & \multicolumn{2}{c}{ Sokoto } & \multicolumn{2}{c}{ Maiduguri } \\
\cline { 2 - 5 } & $\begin{array}{c}\text { MK Statistics } \\
(\mathrm{Z} \text { value })\end{array}$ & P-value & $\begin{array}{c}\text { MK Statistics } \\
(\mathrm{Z} \text { value })\end{array}$ & P-value \\
\hline January & - & - & - & - \\
February & -0.450 & 0.655 & - & - \\
March & 0.250 & 0.805 & -1.680 & 0.094 \\
April & 1.610 & 0.107 & 0.290 & 0.769 \\
May & 1.341 & 0.181 & 0.420 & 0.677 \\
June & 0.320 & 0.746 & 1.130 & 0.260 \\
July & 1.500 & 0.133 & 1.17 & 0.088 \\
August & 0.930 & 0.353 & 2.390 & $0.017 *$ \\
September & 0.670 & 0.503 & 1.51 & 0.130 \\
October & 1.640 & 0.100 & 1.10 & 0.270 \\
November & - & - & - & - \\
December & - & - & -0.56 & 0.576 \\
Overall & 1.10 & 0.271 & 0.730 & 0.463 \\
\hline
\end{tabular}

The MK statistics (z-value) of this analysis showed that Sokoto has no record in January, November, and December respectively, and Maiduguri has no record in January, February, and November. However, there is a significant positive trend in the eight months for both Sokoto and Maiduguri stations, with the two stations having a single difference. The gradient of the trend line varies from $1.640 \mathrm{~mm} / \mathrm{yr}$ (November) to $0.540 \mathrm{~mm} / \mathrm{yr}$ (February) at Sokoto station. The gradient of the trend line at Maiduguri station varies from $2.390 \mathrm{~mm} / \mathrm{yr}$ (August) to $0.29 \mathrm{~mm} / \mathrm{yr}$ (April). This result was different from the observation made by Oloruntade et al. (2018), where the focus was on the coastal region of Nigeria. The annual decrease in rainfall indicates a dry condition in the Northern part of Nigeria and it leads to the depletion in water availability for domestic, agriculture, and industrial use (Oloruntade et al. 2018). Also, the reduction in the rainfall trend may cause drought which is leading to dryness in the streams, rivers, and lakes in the area. According to the report by Goud et al. (2015), the insignificant upward trend in summer rainfall presents an 
opportunity for rainwater harvesting which can be utilized for small-scale irrigation farming during the winter season. Miao et al. (2012) observed similar trends in the variation of rainfall in Beijing, China during summer rainfall.

To compare the monthly rainfall in the two locations, the normality of the rainfall data at Sokoto and Maiduguri stations were tested using Kolmogorov-Smirnov test as shown in Table 5. According to these test results, p-values at Sokoto and Maiduguri stations are less than 0.0001 which indicates that rainfall data were not normally distributed.

Table 5: Kolmogorov- Smirnov test results of rainfall data in Sokoto and Maiduguri.

\begin{tabular}{lcc}
\hline \multicolumn{1}{c}{ Statistic } & Sokoto & Maiduguri \\
\hline Mean & 53.7489 & 47.9777 \\
Standard deviation & 82.23505 & 75.59486 \\
Most Extreme Differences (Absolute) & 0.257 & 0.263 \\
Most Extreme Differences (Positive) & 0.257 & 0.254 \\
Most Extreme Differences (Negative) & -0.257 & -0.263 \\
Kolmogorov-Smirnov Z & 4.959 & 5.069 \\
Asymp. Sig. (2-tailed) & $<0.0001 * *$ & $<0.0001 * *$ \\
Remarks & $\mathrm{NND}$ & $\mathrm{NND}$ \\
\hline **significant at 1\% (p<0.01), NND- Not normally distributed.
\end{tabular}

**significant at $1 \%(\mathrm{p}<0.01)$, NND- Not normally distributed.

The monthly rainfall was also compared using the Mann-Whitney test and the results are shown in (Table 6). The rainfall in May $(\mathrm{p}=0.044)$ and June $(\mathrm{p}=0.049)$ in Sokoto station were significantly higher than that of Maiduguri station. Other than these two months, there is no significant difference in rainfall between Sokoto station and Maiduguri station $(\mathrm{p}>0.05)$.

Table 6: Mann-Whitney test results of monthly rainfall data in Sokoto and Maiduguri.

\begin{tabular}{lllll}
\hline & \multicolumn{3}{l}{ Mean Ranks } & \\
\cline { 2 - 5 } Months & Sokoto & Maiduguri & Z-value & P-value \\
\hline Jan. & 31.50 & 31.49 & 0.0001 & 0.9999 \\
Feb. & 32.00 & 31.00 & -1.0000 & 0.317 \\
March & 32.71 & 30.29 & -0.906 & 0.365 \\
April & 28.48 & 34.52 & -1.381 & 0.167 \\
May & 36.11 & 26.89 & -2.013 & $0.044^{*}$ \\
June & 36.02 & 26.98 & -1.971 & $0.049 *$ \\
July & 33.06 & 29.94 & -0.683 & 0.495 \\
August & 31.13 & 31.87 & -0.162 & 0.871 \\
September & 31.15 & 31.85 & -0.155 & 0.877 \\
Oct. & 30.66 & 32.34 & -0.376 & 0.707 \\
Nov. & 31.50 & 31.49 & 0.0001 & 0.999 \\
Dec. & 31.00 & 32.00 & -1.000 & 0.317 \\
\hline
\end{tabular}

*Significant at $\mathrm{p}<0.05$ 
The summary of the trend analysis carried out using the regression model is shown in (Table 7), and the coefficient of determination was 0.006 and 0.12 for Sokoto and Maiduguri stations, respectively. Thus, the trend equation accounted for $0.6 \%$ and $1.2 \%$ of the variation in rainfall data in Sokoto and Maiduguri stations, respectively. The linear trend is significant at Maiduguri station $(\mathrm{p}<0.05)$ while insignificant in Sokoto station $(\mathrm{p}>0.05)$.

Table 7: Results of the linear trend analysis of rainfall data based on regression model in Sokoto and Maiduguri stations.

\begin{tabular}{llllll}
\hline Location & $\mathrm{R}^{2}$ & $\begin{array}{l}\beta \text { (Trend } \\
\text { coefficient) }\end{array}$ & F-calc. & P-value & Remarks \\
\hline Sokoto & 0.006 & 0.705 & 2.194 & 0.139 & Not significant \\
Maiduguri & 0.012 & 0.930 & 4.544 & $0.034 *$ & Significant \\
\hline
\end{tabular}

The study revealed that mostly it has been dried over decades in the Northern states of Nigeria and the situation may have continued in the $21^{\text {st }}$ century. Although in the months June, July, August, and September (JJAS), there are increases in the annual rainfall with the peak in June and September, this signifies the summer months in the country. However, due to the increase in rainfall in JJAS months, we suggest that the government should be more proactive by constructing more dams with more water storage facilities. Moreover, due to the rapid growth in the urban areas where the high rate of flood has been experienced, it is suggested that the government should make it a point of duty to provide appropriate water channels to enhance water flow. Furthermore, the result of the present study could serve as a source of information to farmers in the Northern state to adequately make use of this period of JJAS for their planting season and enlightened the groundwater geoscientist in the exploration and exploitation of portable water quality and sustainability within the study areas.

\section{Conclusion}

The modelled statistical approach on rainfall trends and variability revealed that the peak months of annual rainfall is between June and September respectively. Farmers, groundwater geoscientists and drainage engineers should therefore make proper plans to utilize rainwater received during this period and monitor the surface-water flow to avoid flood tide. Thus, the government should make favourable policies to utilize the extensive rainfall received during this period to store more water by the construction of dams and water channels/drainage across the country. This will also help to provide portable quality water resources and minimize flood events that have been experienced across the country. 


\section{Acknowledgements}

The authors wish to express their profound gratitude to the Nigeria Meteorological Agency (NiMet), for the provision of data for this research. We also appreciate the anonymous reviewers of RJS.

\section{References}

Abaje IB, Ati OF, Iguisi EO. 2010. An Analysis of Rainfall Trends in Kafanchan, Kaduna State, Nigeria. Research Journal of Environmental and Earth Sciences 2(2): 89-96.

Abdul Aziz OI, Burn DH. 2006. Trends and variability in the hydrological regime of the Mackenzie River Basin. Journal of Hydrology 319(1): 282-294.

Adefolalu DO. 2007. Climate change and economic sustainability in Nigeria. In: Paper presented at the International Conference on Climate Change and Economic Sustainability held at Nnamdi Azikiwe University, Enugu, Nigeria, 12-14 June 2007.

Akinsanola AA, Ogunjobi KO. 2014. Analysis of Rainfall and Temperature Variability over Nigeria. Global Journal of Human-Social Science (B) Geography,Geo-Sciences, Environmental Disaster Management 14(3): 10-28.

Anghileri D, Pianosi F, Soncini-Sessa R. 2014. Trend detection in seasonal data: from hydrology to water resources. Journal of Hydrology 511: 171-179.

Goud S, Biradar V, Janagoudar BS, Shanwad UK, Sreenivas AG. 2015. Implications of rainfall distribution pattern and its variability for crop planning of crops: A study in Northeastern transitional zone of Karnataka. Karnataka Journal of Agricultural Sciences Spl. Issue 28(5): 746-752.

Houghton JT, Meiro Filho LG, Callander BA, Harris N, Kattenburg A, Maskell K. 1996. Climate change 1995: the science of climate change. Climatic Change $584 \mathrm{pp}$.

Miao LI, Jun X, Dejuan M. 2012. Long-term Trend Analysis of Seasonal Precipitation for Beijing, China. Journal of Resources and Ecology 3(1): 064-072.

Mondal A, Kundu S, Mukhopadhyay A. 2012. Rainfall Trend Analysis by Mann-Kendall Test: A Case Study of North-Eastern Part of Cuttack District, Orrissa. International Journal of Geology, Earth, and Environmental Sciences 2(1): 70-78.

Oguntunde PG, Abiodun BJ, Lischeid G. 2011. Rainfall trends in Nigeria, 1901-2000. Journal of Hydrology 411: 207-218.

Oloruntade AJ, Mogaji KO, Imoukhuede OB. 2018. Rainfall trends and variability over Onitsha, Nigeria. Ruhuna Journal of Science. 9(2), 127-139.

Salami T, Maatta A, Anttila, P, Ruoho-Airola T, Amnell T. 2002. Detecting Trends of Annual Values of Atmospheric Pollutants by the Mann-Kendall Test and Sen's Slope Estimates. Publications on Air Quality, No. 31. Helsinki, Finland.

Shahid S. 2010. Rainfall variability and the trends of wet and dry periods in Bangladesh. International Journal of Climatology 30(15): 2299-2313.

Smith M. 2000. The application of climatic data for planning and management of sustainable rain-fed and irrigated crop production. Agriculture and Forest Meteorology 103: 99-108.

Wang D, Hejazi M, Cai X, Valocchi AJ. 2011. Climate change impact on meteorological, agricultural, and hydrological drought in central Illinois. Water Resources Research 47: W09527.

Xu Z, Liu Z, Fu G, Chen Y. 2010. Trends of major hydroclimatic variables in the Tarim River basin during the past 50 years. Journal of Arid Environment 74: 256-267. 